\title{
TITLE:
}

\section{ON A NEW GENUS OF THE FAMILY OOCORYIDAE}

$\operatorname{AUTHOR}(\mathrm{S})$ :

Kuroda, Tokubei; Habe, Tadashige

\section{CITATION:}

Kuroda, Tokubei ...[et al]. ON A NEW GENUS OF THE FAMILY OOCORYIDAE. PUBLICATIONS OF THE SETO MARINE BIOLOGICAL LABORATORY 1957, 6(1): 27-29

ISSUE DATE:

1957-06-30

URL:

http://hdl.handle.net/2433/174575

RIGHT: 


\title{
ON A NEW GENUS OF THE FAMILY OOCORYIDAE ${ }^{122}$
}

\author{
TOKUBEI KURODA \\ Zoological Institute, Kyoto University \\ and \\ TADASHIGE HABE \\ Amakusa Marine Biological Laboratory, Kyushu University
}

With 5 Text-figures

In 1907, DALL') described Galeodea leucodoma based on the specimen collected by the "Albatross" from off Kagoshima, Japan, in 391 fathoms which was later figured in 1925. ${ }^{2}$ Fortunately, this deep sea species has been recently rediscovered from Tosa Bay by Mr. Akibumi Teramachi who kindly placed the specimen containing the soft part at our disposal.

The dissection has revealed that this species should be transferred from the family Cassididae to the Oocoryidae by the following features: viz, the radula has a subquadrate central tooth bearing a triangular median cusp with several smaller lateral cusps on each side and the horn-shaped marginal teeth with a single cusp.

The shell of this species resembles somewhat G. echinophora (LINNE), the type species of Galeodea LiNK, but differs in the short and less curved canal, without any crevices at the base behind the columellar reflection of lip. And the operculum is large enough, oblong and thick, dark brown, pointed behind, rounded in front; outer margin somewhat laminately erecting, forming a deep furrow on the inside of it; growth striae distinct; nucleus excentric, situated at the anterior three-fourths near the outer margin; subspiral.

This species closely relates to Oocorys caribbaea ClenCH and AguAyo from the West Indies in having the distinctly nodular spiral series, the number of which is less than those of the other species of Oocorys and the shell is sufficiently solid.

Therefore, a new generic name, Galeoocorys is here proposed, designating Galeodea leucodoma DALL as the type species. The other member of this new genus may be "Morio" granulosa SchepMAN $^{3}$ ) from Indonesian sea, which has finer series of nodules than our species.

1) Contributions from the Seto Marine Biological Laboratory, No. 292.

2) Contributions from the Amakusa Marine Biological Laboratory (Kyushu University) No. 100.

Publ. Seto Mar. Biol. Lab., VI (1), 1957. (Article 2) 
On this occasion, we shall deal with a species of Japanese Tonnidae. In 1948, Dr. R. TURNER ${ }^{4}$ pointed out the fact that the Japanese specimen figured by OsIMA ${ }^{5}$ ) does not agree with Eudolium lineatum (SCHEPMAN) which should be a member of
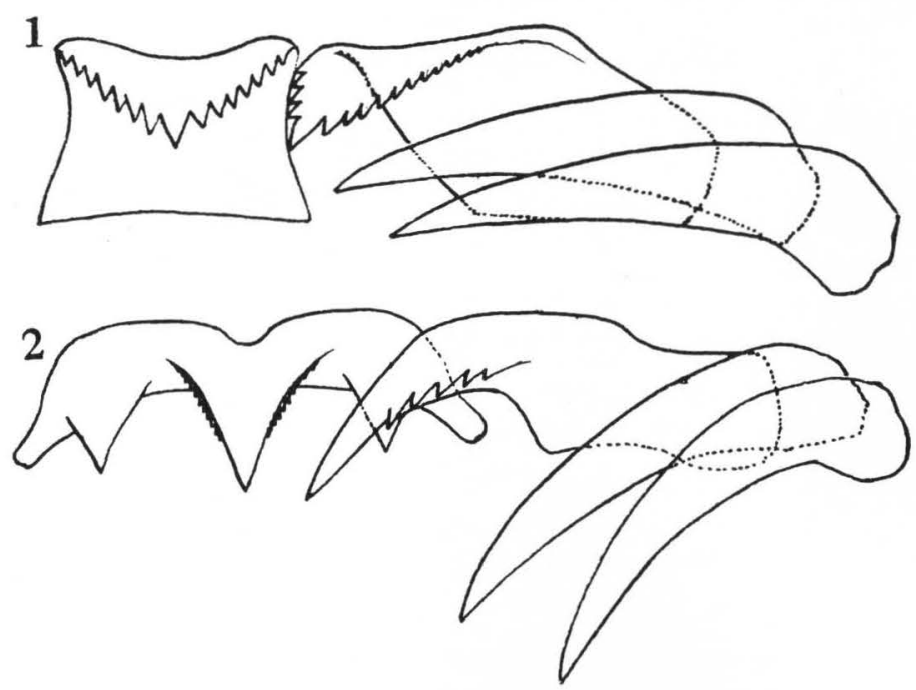

Figs. $1 \&$ 2. Radulae: 1. Galeoocorys leucodoma (DALL), 2. Eudolium inflatum KuRODA et HABE.

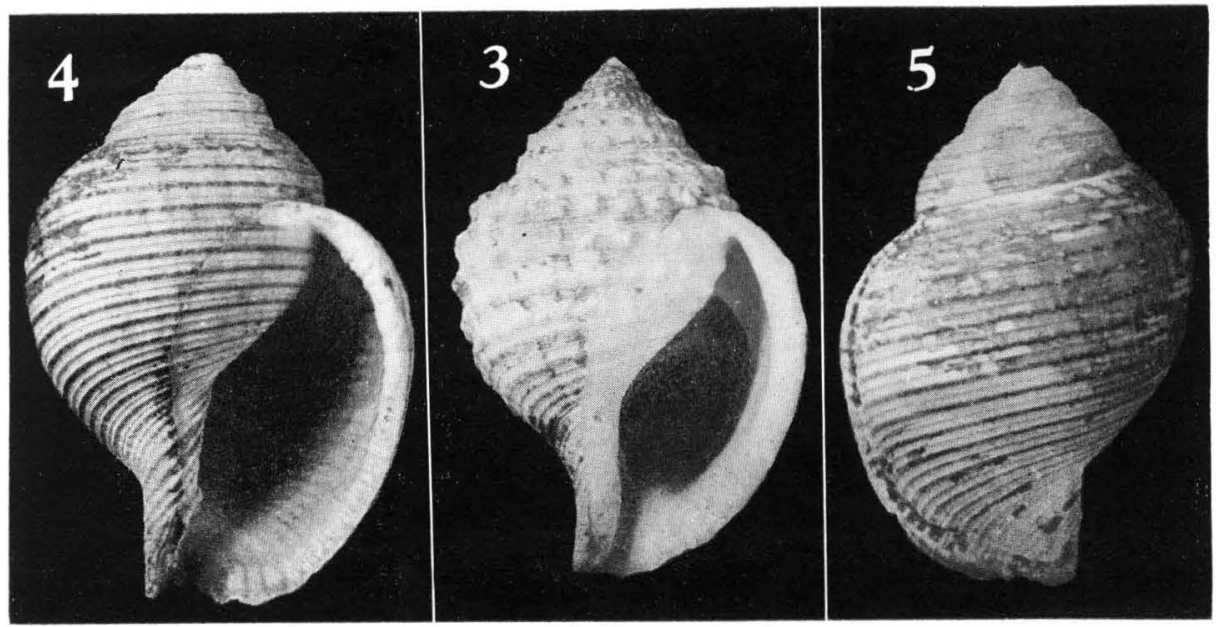

Figs. 3 5. Shells: 3. Galeoocorys leucodoma (DALL) (64 $\mathrm{mm}$ in height and $43 \mathrm{~mm}$ in breadth.), 4 \& 5. Eudolium inflatum KuRODA et $\mathrm{HABE}$ ( $65 \mathrm{~mm}$ in height and $45.5 \mathrm{~mm}$ in breadth).

Oocoryidae, standing close to Eudolium crosseanum (Monterosato) from the Atlantic. The Japanese species is a real Eudolium with the embryonic shell peculiar to Macgillivrayia, and we already discriminated it giving a new name, Eudolium inflatum. ${ }^{6}$ ) 
The radula of this species bears a large median cusp with many minute lateral cusps on each side of it and a large basal cusp on each side of the central tooth. Therefore it belongs to the typical group of the genus Eudolium, but not to Oocorys, as stated by Dr. R. Turner.

\section{REFERENCES}

1) Smithsonian Misc. Coll., 50, 166 (1907).

2) Proc. U. S. Nat. Mus., 66 (17), 17, pl. 34, fig. 4 (1925).

3) Siboga Expeditie, 41 (1), Prosobranchia, p. 123, pl. 10, fig. 4 (Morio granulata in the explanatory text).

4) Johnsonia 2 (26), 176 (1948).

5) Conchologia Asiatica, I, 133, pl. 5, fig. 1 (1943).

6) Check List Bibliogr. Rec. Mar. Moll. Japan, 56 (1952). 